\title{
Catarsis e experiência receptiva na "Estética" (1963) de Georg Lukács
}

\section{Catharsis and aesthetic experience in Georg Lukacs' "Aesthetics" (1963)}

Renata Altenfelder Garcia Gallo

Doutora em Teoria e História Literária pela Universidade de Campinas (UNICAMP) e Professora do Colégio

Técnico da Unicamp (COTUCA), Campinas-SP.

florrag@yahoo.com.br

(1) https://orcid.org/0000-0002-8009-9965

Recebido em: 12/12/2018

Aceito para publicação em: 13/11/2018 


\section{Resumo}

Neste artigo, descreveremos de que forma a experiência estética da recepção e a ideia de catarsis estão presentes na estética de maturidade de Georg Lukács, considerando que o seu projeto original foi organizado em 3 partes: a particularidade do fato estético, os problemas do reflexo artístico e, por fim, a tipologia filosófica do comportamento estético. Octogenário, Lukács finalizou, somente, a primeira parte da obra, em 1963. Apesar de sinalizar ao leitor que noções relativas ao comportamento estético seriam discutidas na terceira parte da obra, o autor faz apontamentos acerca da experiência receptiva e da ideia de catarsis, que serão, neste estudo, retomadas.

Palavras-chave: Georg Lukács.

Estética. Experiência receptiva.

Catarsis.

\section{Abstract}

The aim of this study is to describe how the aesthetic experience and the idea of catharsis are presented in Georg Lukacs'late aesthetics, considering that his original project was organized in three parts: the particularity of the aesthetic fact, the problems of the artistic reflection and, finally, the philosophical typology of aesthetic behavior. Unfortunately, Lukacs wrote only the first part of the work, in 1963. Although he pointed out to the reader that some important considerations about the aesthetic behavior would be discussed in the third part of his study, the author wrote some notes about the receptive experience and the idea of catharsis, which will be presented in this essay.

Keywords: Georg Lukacs. Aesthetics. Aesthetic Experience. Catharsis. 
Introdução

Ao longo de seu percurso intelectual, o filósofo húngaro Georg Lukács (1885-1971) demonstrou vasto interesse acerca da esfera artística, o que o levou a escrever, apoiandose em bases metodológicas distintas, duas estéticas. A estética de juventude (1912-1918) foi escrita em dois momentos diversos, o que resultou em dois textos complementares, intitulados "Filosofia da Arte", redigida entre os anos de 1912 e 1914, e a "Estética de Heidelberg", produzida entre 1916 e 1918 . Dentre as diversas influências que esses textos apresentam, as mais marcantes são aquelas da filosofia neokantiana, da Lebensphilosophie e dos escritos de Hegel.

A segunda redação do projeto estético lukacsiano, cuja publicação da primeira parte se deu em 1963, foi pensada a partir da teoria de Karl Marx e de Friedrich Engels. Ao iniciar a composição da estética de maturidade, na década de 1950, seu autor pretendia a redação de uma obra que consistiria, primeiramente, em duas partes; contudo, os seus planos originais sofreram modificações, o que o impeliu à escrita de um terceiro tomo. Originalmente, a primeira parte se ocuparia da particularidade do fato estético; a segunda, se ateria aos problemas do reflexo estético, tomando por objeto a estrutura da obra de arte e a tipologia filosófica do comportamento estético; e, por fim, a terceira parte discutiria a questão da arte como fenômeno histórico-social. Entretanto, Lukács, já octogenário, conseguiu finalizar, apenas, a primeira parte do texto, publicada em 1963. Embora o autor não tenha concluído o seu projeto original, podemos encontrar na "Estética" alguns indícios, ou mesmo, o desenvolvimento, ainda que breve, de temas que seriam analisados nas partes seguintes da obra, como é o caso da experiência receptiva da obra de arte e da noção de catarsis, que serão, neste estudo, retomadas.

Realizada essa breve introdução, reproduziremos, a seguir, um importante apontamento de Lukács sobre a experiência da recepção na "Estética". É importante mencionarmos que as considerações lukacsianas sobre essa temática bem como sobre a ideia de catarsis se concentram, essencialmente, no segundo volume da edição espanhola da "Estética", publicado pela editora Grijalbo, em que o autor discute os problemas relacionados à mimese:

É impossível, aqui, naturalmente, decompor analiticamente o complicado quadro da recepção e mostrar tipologicamente seus diversos níveis, diferenças, etc., desde a simples recepção da obra até os graus superiores da consciência estética, isso pertence ao ciclo de tarefas da segunda parte (LUKÁCS, 1972, vol. 2, p. 491, tradução nossa). 
Pensada inicialmente por Lukács, a segunda parte da "Estética" se ateria às questões concernentes ao reflexo artístico, concentrando-se na estrutura da obra de arte e na tipologia filosófica do comportamento estético: o processo de recepção e de criação dos objetos artísticos. Como já mencionado, o autor não escreveu a segunda parte da obra, mas não nos poupou de considerações robustas sobre os temas da recepção e da catarsis, acerca dos quais nos ateremos a seguir.

\section{A experiência receptiva na "Estética"}

Discutir de que modo se dá a relação entre sujeito e objeto no momento da recepção das obras de arte sempre foi um dos eixos centrais daqueles que se propuseram a pensar os problemas concernentes à estética. Lukács não se furtou ao enfrentamento dessa problemática, realizando diversos apontamentos sobre o tema, os quais nos permitem, de certa forma, traçar uma moldura consistente de suas ideias acerca da experiência receptiva no âmbito da estética. Nesse sentido, uma das primeiras considerações lukacsianas importantes acerca da temática é a da duplicidade específica do comportamento receptivo na esfera estética. Para explicá-la, o autor se atém a dois pontos: o primeiro deles consiste no caráter puro ou predominante de conteúdo que a vivência artística comporta, de modo que a relação entre o fruidor e a obra só se concretiza esteticamente se nasce conscientemente da evocação do conteúdo; implicando a ideia de que o fruidor é apresentado, no momento da experiência receptiva do objeto artístico, a um mundo novo, que, concomitantemente, é, para ele, um tanto familiar. Essa noção de familiaridade com o mundo refigurado na obra é necessária para que o efeito autenticamente estético seja produzido. O segundo ponto da duplicidade específica do comportamento receptivo consiste na noção de que a experiência estética não pode ser alcançada a menos que seja evocada pelas formas da obra de arte. O autor, portanto, concentra a efetivação da experiência receptiva em dois elementos: a relação do sujeito com o conteúdo da obra e com a sua respectiva forma.

Compreendida dessa maneira, a experiência receptiva nos revela que Lukács entende a obra de arte como um objeto que compreende uma relação intrínseca entre forma e conteúdo, configurada, para o autor, a partir da ideia de que toda a forma é a forma de um conteúdo determinado. Nesse sentido, emana do conteúdo a ser refigurado pela obra a sua forma artística adequada, que vem à tona a partir de um processo de elaboração da matéria pelo artista: "Isso implica que cada novo conteúdo, cada nova expressão do real, demanda uma nova forma estética e, portanto, uma outra conformação do particular" (CARLI, 2012, p. 124). 
A partir dos aspectos mencionados, não se pode negar a indissolubilidade entre forma e conteúdo na "Estética", bem como é importante sublinhar a ideia do conteúdo como fator determinante nessa relação. Segundo Carli: “(...) temos a primazia do conteúdo extraído do movimento do real sobre a forma gerada, em última instância, pelo sujeito artístico" (CARLI, 2012, p. 124). Para Lukács, a forma artística é um meio de expressão de um conteúdo essencial presente na evolução da humanidade. A relação bem sucedida de forma e conteúdo produz, por sua vez, um efeito evocativo concreto e geral, que é, igualmente, uma necessidade social.

Esse processo, de acordo com Lukács, tem como ponto de chegada a transformação do homem inteiro, entendido como o sujeito da vida cotidiana, em homem inteiramente, o homem em sua plenitude, orientado, assim, para a universalidade de um meio homogêneo. O conteúdo humano dessa transformação pode ser colocado nos seguintes termos: o sujeito fruidor, no momento da contemplação da obra, se afasta relativamente do plano da vida cotidiana para:

[...] se orientar exclusivamente e temporalmente à contemplação de um aspecto vital concreto, que refigura o mundo como totalidade intensiva das determinações decisivas que são oferecidas a partir de certa perspectiva (LUKÁCS, 1972, vol. 2, p. 495, tradução nossa).

Afirma-se, portanto, que o sujeito fruidor se abre a um tipo de relação com o objeto que tem como marca um comportamento receptivo, o qual acolhe, imediatamente, o objeto da contemplação. Para que isso seja possível, é um traço da experiência receptiva a suspensão das tendências ativas do homem e da sua vontade de intervir efetivamente nos dados concretos do mundo que o rodeia. Estamos falando, portanto, de uma experiência voltada à contemplação, que, por meio da evocação do conteúdo e da forma do objeto artístico sob as vivências particulares do sujeito estético, produzem nesse indivíduo um comportamento que o impele à imediata suspensão de sua vontade de agir no mundo, levando-o a se concentrar, somente, no objeto artístico. De modo contrário, é caracterizado o comportamento da criação artística, cujo princípio dominante é aquele ativo, balizado pela transformação progressiva dos conteúdos essenciais da vida em identidade de forma e conteúdo.

Para que se opere a transformação do homem inteiro em homem inteiramente, Lukács acentua a importância do meio homogêneo. Na esfera estética, tal meio é compreendido pelo autor como um aspecto que penetra a vida anímica do receptor, orientando e evocando as suas vivências no ato da fruição, de forma a subjugar o seu modo habitual de contemplar o mundo, ofertando-Ihe um mundo novo, preenchendo-lhe de novos conteúdos ou ofertando-lhe uma maneira nova de concebê-los. O resultado 
dessa experiência tem como consequência a recepção e a apropriação pelo sujeito fruidor de um mundo com sentidos renovados, o que amplia e enriquece os conteúdos de sua psique.

Lukács nos atenta, por conseguinte, que o sujeito receptor não deve ser entendido como uma tábula rasa ou uma folha em branco diante da obra. Até mesmo quando esse sujeito é uma criança, o autor ressalta que a sua vida já fora preenchida de vivências, experiências, impressões ou pensamentos que agirão, de certa forma, sobre ele. Lukács, entretanto, afirma que os conflitos que podem resultar dessas questões são de diversas ordens e, portanto, fala que não tratará deles, na "Estética", de forma ensaística ou a partir de uma tipificação provisória:

Observemos simplesmente que seria trivial e desorientada uma limitação social absoluta das possibilidades de eficácia das obras de arte, como, por exemplo, uma limitação segundo a qual uma obra nascida sob uma base de classe proletária não poderia ter eficácia alguma na burguesia, ou vice-versa [...] (LUKÁCS, 1972, vol. 2, p. 497, tradução nossa).

Para justificar a passagem citada, o próprio autor resgata "As Bodas de Fígaro", redigida por Pierre-Augustin Caron de Beaumarchais, as obras de Gorki e de Brecht, bem como o filme "O Encouraçado Potemkin", de Serguei Eisenstein, como exemplos representativos de como os mais diversos objetos estéticos alcançam homens de características múltiplas e penetram as suas mentes, ressoando, portanto, em seu interior. O autor é bastante enfático ao ressaltar que:

[...] é perfeitamente possível que uma sensibilidade artística viva e apaixonada e o pressentimento de sua infalível ineficácia entrem em conflito com as tarefas vitais do homem inteiro que vive na realidade" (LUKÁCS, 1972, vol. 2, p. 497, tradução nossa).

Em suas recordações sobre Lenin, Gorki conta que, ouvindo uma reunião de sonatas de Beethoven, aquele declarou não conhecer nada mais charmoso que a "Apassionata". Sobre ela, afirmou que poderia ouvi-la diariamente, pois era extraordinária. Disse, ainda, segundo Gorki, com um orgulho um tanto ingênuo, que os homens são capazes de produzir tais milagres, mas, ao enxugar os olhos, sorriu e emendou que não podia ouvir música com tanta frequência, pois elas afetavam seus nervos, suscitavam nele o desejo de falar bobagens e de acariciar a cabeça dos homens que viviam neste "porco inferno", mas que eram capazes, apesar dos pesares, de produzir tantas belezas. Proferiu, por fim, que, naquele momento, não mais era permitido acariciar a cabeça de ninguém. Essa recordação de Gorki, trazida por Lukács, na "Estética", ilustra o poder do qual a arte autêntica dispõe de submeter os sujeitos à recepção dos objetos mesmo quando há resistência de alguns indivíduos de superação do homem inteiro pelo homem inteiramente. Os exemplos 
mencionados por Lukács são representativos no que tangem à ideia de que a experiência receptiva e a relação entre sujeito e obra de arte devem ser entendidas a partir do potencial do objeto de estabelecer um meio homogêneo na vida anímica do receptor, que evoque, oriente e conduza as vivências do sujeito estético. Esse potencial se efetiva quando o artista consegue plasmar um conteúdo artístico no objeto por meio da forma artística que é evocada pelo próprio objeto da representação. É esse processo que permite que os múltiplos sujeitos, das mais distintas classes sociais e que dispõem dos mais diversos interesses estabeleçam uma experiência de recepção com o mesmo objeto estético. Não poderíamos deixar de mencionar, por exemplo, a pintura de Michelangelo Buonarroti no teto da Capela Sistina. Embora saibamos que tais afrescos exerçam um apelo espiritual e religioso na psique de alguns indivíduos, efetivando o interesse nessas obras e impulsionando a experiência estética, sabemos, ainda, que muitos sujeitos se relacionam esteticamente com esses afrescos apesar de não serem adeptos ou simpatizantes de nenhum tipo de religião. A vivência estética desses indivíduos pode ser diversa devido às suas múltiplas orientações e interesses, mas não se pode negar que ela se efetiva no plano estético.

\section{Catarsis e experiência receptiva na "Estética"}

O poder evocador da obra de arte de conduzir o sujeito à fruição estética, possibilitando a transformação do homem inteiro da vida cotidiana em homem inteiramente, nos conduz à noção lukacsiana de catarsis, categoria que, por sua vez, opera de forma particular em cada um dos sujeitos, ao mesmo tempo em que os impulsiona à generalização. Antes de desenvolvermos mais amplamente essa ideia, é importante mencionarmos a vinculação da estética antiga e de suas sucessoras modernas a uma postura que justifica o real papel social da arte. O posicionamento dessas estéticas está alinhado à ideia de que o poder das vivências artísticas influencia o homem de forma intensa, podendo, assim, transformá-lo. Afirma Lukács, portanto, que a estética antiga descobre a sua função social a partir da noção de que:

[...] um determinado exercício de determinadas artes é parte das forças transformadoras da vida humana e, portanto, da vida social; que a arte é capaz de influenciar os homens e as direções de efeito promotor ou inibidor da formação de determinados tipos humanos (LUKÁCS, 1972, vol. 2, p. 499, tradução nossa).

Essa concepção rechaça, por conseguinte, as teorias que visam distanciar e isolar o estético e a vida social dos sujeitos. Ao retomar Lessing, Lukács alega que este autor resume de forma adequada o efeito social da arte para a estética da antiguidade, o qual consiste "na transformação das paixões em disposições virtuosas". Para Aristóteles, o 
efeito produzido pela música, por exemplo, não se limita, apenas, à ideia de um prazer sensível, mas promove, sobretudo, um efeito ético, de modo que essa arte "influencie o caráter e as almas". Em sua "Poética", o filósofo grego define a tragédia como "imitação de uma ação de caráter elevado, completa e de certa extensão, em linguagem ornamentada", acrescentando que, "suscitando o terror e a piedade, tem por efeito a purificação dessas emoções" (ARISTÓTELES, 1993, p. 37). Essa purificação das emoções corresponde, justamente, à ideia aristotélica de catarsis, a qual está intrinsecamente relacionada ao gênero trágico. Para o filósofo, o enredo é o elemento fundamental da tragédia, de forma que é possível defini-lo como a imitação de uma ação cujo télos, ou seja, a sua finalidade é, logo, o seu efeito, o seu érgon. Esse érgon é a catarsis, que tem por efeito a purificação das emoções humanas. Nesse sentido, pode-se assegurar que o efeito catártico coroa a experiência de recepção da obra trágica. Tomando por base essa afirmação, Lukács pondera que a noção de catarsis, aplicada apenas à tragédia, aos afetos voltados ao terror e à piedade, tal como postulou Aristóteles, deve ser ampliada.

Nesse sentido, Lukács afirma que, como todas as categorias estéticas, a catarsis tem sua origem primária na vida e, não, na arte, de forma que ela foi e permanece um momento constante e significativo da própria vida social dos homens. Se a obra de arte refigura os conteúdos próprios da vida humana e se a catarsis tem sua origem na vida dos homens, como acredita Lukács, a correspondência entre as categorias estéticas e aquelas presentes na vida humana é um princípio constante que embasa a estética deste autor:

Toda arte, todo efeito artístico, contém uma evocação do núcleo vital humano - o que suscita em cada receptor a pergunta goethiana se ele é núcleo ou casca-, e, ao mesmo tempo, inseparavelmente a ela, uma crítica da vida (da sociedade, da relação que ela produz com a natureza). E como, de acordo com o que foi visto, a vivência receptiva tem que ser desde o ponto de vista imediato uma vivência de conteúdo, a vivência mesma manifesta esse complexo problemático como conteúdo central do mundo que a obra de arte desperta e vivencia (LUKÁCS, 1972, vol. 2, p. 501, tradução nossa).

Como já mencionamos, o entendimento da noção de catarsis deve ser ampliado, segundo Lukács, pois esta não nasce simplesmente da estrutura da obra de arte considerada em si mesma. Em sua identidade de forma e conteúdo, o objeto artístico concentra dois complexos importantes, os quais estão intrinsecamente relacionados. São eles, o da própria obra com a realidade objetiva que possibilitou o seu nascimento; e o da possibilidade de suscitar e despertar alguma influência na alma do sujeito receptor. A imbricada relação entre esses dois complexos nos conduz à afirmação de que, quanto mais amplos e profundos são os conteúdos que a forma artística põe em identidade 
consigo mesma, mais amplos e de mais profundo alcance torna-se a relação entre esses dois complexos. A função humana e social da arte reside, essencialmente, neste ponto.

A recepção artística das autênticas obras de arte, entendida por Lukács como a transformação do homem inteiro da vida cotidiana em homem inteiramente, aproxima os indivíduos de uma formação humana omnilateral, de modo a impulsionar um possível rompimento com a formação unilateral e limitada presente de forma massiva na sociedade capitalista. Resgatando Goethe e a sua ideia do homem como núcleo ou casca, Lukács afirma que, para o escritor alemão, a missão mais importante da arte consiste em conduzir e despertar o homem à sua situação de núcleo. Por tal motivo, uma relação adequada com o mundo externo é, sempre, decisiva para o sujeito e para que ele se veja como núcleo e não, somente, como casca. A familiaridade do externo e do interno formulada por Goethe em seu estudo da natureza é absorvida por Lukács em sua argumentação sobre a ampliação do sentido da catarsis. Ao resgatar a afirmação do autor alemão de que as artes plásticas estão ligadas ao visível, isto é, à manifestação externa do natural, Lukács sublinha que a noção de natural está associada não, somente, a algo visualmente objetivo, mas, ainda, a algo humano e ético, a saber, socialmente moral. Soma-se a esse conjunto de ideias, a observação conclusiva de Goethe de que todo objeto artístico deve ser julgado segundo a sua adequação para ser "uma expressão ética do natural":

Dessa forma Goethe colocou o fundamento filosófico de nossa generalização da catarsis para a arte em geral e para as artes plásticas em particular. Pois se a relação visual do homem frente aos objetos naturais, ao seu conjunto, é uma relação ética e recordamos outra vez o que dissemos sobre o intercâmbio da sociedade com a natureza -, por conseguinte, no efeito que produz sua refiguração artística é gerada uma comoção que, com fundamento, pode se chamar de ética. Imediatamente, se mescla à comoção do receptor, pelo novo que cada obra individual nele desencadeia, um sentimento concomitantemente negativo, um pesar, uma espécie de embaraço por nunca haver percebido na realidade, na própria vida, o que tão naturalmente se oferece na conformação artística (LUKÁCS, 1972, vol. 2, p. 507, tradução nossa).

O significado dessa passagem caminha na direção da afirmação de que a catarsis estética é um reflexo concentrado e conscientemente produzido de comoções, que, no plano da vida cotidiana, ocorre de forma espontânea e simultânea aos acontecimentos que permeiam a vida dos sujeitos. Ao entrar em contato com a obra de arte, o sujeito fruidor percebe uma elevação do mundo fetichizado a um mundo de caráter verdadeiramente humano, revelado, assim, pela experiência catártica, que proporciona a humanização do receptor. Em outras palavras, é correto afirmar que essa elevação do mundo fetichizado a um mundo verdadeiramente humano é a experiência originada pela catarsis. Nesse sentido, afirmamos que a catarsis assevera a missão desfetichizadora da arte, que se realiza por meio de dois movimentos: 1) a revelação ao homem da fetichização da vida 
cotidiana em que está inserido e 2) o movimento de defesa da integridade da humanidade no plano dessa mesma vida cotidiana. Desse modo, a obra de arte se torna um veículo também pedagógico, pois possibilita ao receptor, diante da obra, a percepção "natural" de alguns aspectos da vida, que, no plano da vida cotidiana, ficam obscurecidos pelas próprias particularidades dessa esfera, como a dispersão. Esse movimento nos leva à compreensão lukacsiana da arte como crítica da vida e como forma de transformação da existência.

Podemos afirmar, diante dos movimentos previamente descritos, que a imediaticidade própria da esfera estética, quando comparada à da vida cotidiana, é uma imediaticidade superada, pois consiste na produção de uma nova imediaticidade não observável em nenhum outro plano. É inegável que os conteúdos gerais e essenciais da vida humana se encontram de forma latente na imediaticidade da vida cotidiana, entretanto, esses conteúdos devem ser descobertos e revelados, ao passo que, na imediaticidade própria do campo da arte, os conteúdos gerais e essenciais da evolução humana aparecem, simultaneamente, ocultos e manifestos. Essas particularidades estruturais conferem ao objeto estético a possibilidade de criação de um mundo novo em que os conteúdos essenciais da vida cotidiana são selecionados, reagrupados e depurados pela forma artística, o que causa certa mudança funcional na estrutura de mundo da vida cotidiana. Esse movimento leva, por fim, à criação de um mundo fechado e adequado, o qual pode ser recebido pelo sujeito conforme as suas necessidades vivenciais e à sua capacidade de recepção.

A desfetichização e a catarsis são meios pelo quais a arte realista realiza o seu papel na formação dos homens, pois reconcilia o sujeito com o mundo do qual ele se separou. Esse movimento permite que o indivíduo se reconheça no mundo dos objetos, assegurando a possibilidade da identidade sujeito-objeto denegada pelo trabalho estranhado e fetichizante. Desta feita, a objetivação humana não está rendida à fetichização e à alienação, pois o homem pode, por meio da experiência estética, se reconhecer no mundo dos objetos e se sentir parte desse mundo do qual é co-criador, restabelecendo, por conseguinte, a relação entre o homem inteiro e o homem inteiramente, a qual não vigora na vida reificada. Esse conjunto de noções somente corrobora a ideia de que a arte se apresenta como um meio para que o homem possa retornar ao mundo cotidiano e, nele, construir uma relação sujeito-objeto autêntica. Nesse sentido, a experiência catártica conduz o sujeito a viver o mundo como sua pátria, de forma que ele pode se reconhecer como parte do gênero humano, vislumbrando tudo aquilo que fora construído historicamente pela humanidade. A partir dessa experiência, o sujeito estético pode vivenciar o sentido humano, profundo e, por fim, amplo de sua vida singular, sem que seja necessário o apagamento de suas singularidades. Ele pode, ainda, 
experimentar a sua construção como ente universal e genérico, ou seja, como parte da humanidade.

Enfatizamos, destarte, a tarefa da forma artística na "Estética", que consiste, justamente, em “(...) tornar universalmente vivenciável um conteúdo relevante para a humanidade" (LUKÁCS, 1972, vol. 2, p. 518, tradução nossa). É necessário lembrar a primazia do conteúdo sobre a forma afirmada por Lukács na obra, atentando que, somente um conteúdo intrinsecamente relacionado ao destino da humanidade, ou seja, essencial, pode originar uma atribuição de forma realmente profunda pelo artista ao objeto que pretende configurar. Resgatamos, portanto, um princípio essencial da estética para o autor, o de que a forma é sempre a forma de um conteúdo determinado, de modo que nem o mais grandioso artista pode realizar a identidade de forma e conteúdo no objeto estético se a relação entre estes é inexistente ou incipiente. O efeito duradouro ou transitório de uma obra bem como de sua recepção estão intimamente ligados a este princípio. Para Lukács, portanto, a vivência estética genuína é uma vivência de conteúdo. Essa afirmação pode soar um bocado estranha, mas é justificada a partir do entendimento da forma artística como elemento que possibilita a materialização de um mundo homogeneamente unitário e, ao mesmo tempo, complexo, concebido de modo a se referir ao sujeito receptor no que tange tanto às suas partes quanto ao todo da configuração, funcionando, por sua vez, como um mundo, ou seja, como conteúdo.

Retomando o conjunto de noções congregadas por Lukács no âmbito da recepção artística, é possível afirmar a elevação do sujeito fruidor diante da vida cotidiana pelo efeito da catarsis, movimento que desencadeia um choque entre o mundo objetivo refletido esteticamente pela obra e a subjetividade cotidiana, ampliando e enriquecendo as vivências do sujeito receptor, aspecto igualmente perceptível na seguinte observação de Lukács:

[...] o homem se orienta necessariamente na vida para ações, decisões, etc., individuais, isoladas, enquanto que em sua atitude diante da obra de arte é suspensa temporalmente essa vinculação entre as vivências e as ditas manifestações concretas da realidade, de tal modo que [o homem] se entrega à vivência estética de cada caso com sua personalidade total, sem que as consequências desses efeitos possam se revelar, senão no Depois da recepção, por isso tais consequências têm que ser ainda mais multívocas e mais ricas em estratos do que os efeitos produzidos pela própria vida (LUKÁCS, 1972, vol. 2, p. 510, tradução nossa).

Lukács enfatiza, assim, a importância da distinção entre os momentos do Antes e do Depois na experiência da fruição estética. Embora estes se dêem de forma simultânea e seus limites se manifestem de maneira tênue na imediaticidade da vivência, eles são essenciais para que sejam ativadas e sacudidas as paixões vitalmente ativas do receptor, 
no sentido de que estas possam recobrar novos conteúdos, novos caminhos e, assim que purificadas, "(...) se convertam em embasamento anímico de disposições virtuosas" (LUKÁCS, 1972, vol. 2, p. 508, tradução nossa). A recepção estética, por meio da catarsis, promove, assim, certo confronto entre os conteúdos pessoais do receptor e aqueles vivenciados na obra; aspecto que possibilita uma mudança de orientação dos seus conteúdos internos após o momento da fruição. Sobre o efeito catártico, Lukács afirma:

\begin{abstract}
[...] não se reduz, por conseguinte, a mostrar novos aspectos da vida ou a iluminar com novas tonalidades aspectos já conhecidos pelo receptor, mas a novidade qualitativa da visão que assim nasce altera a percepção e a capacidade e a torna apta para a percepção de novas coisas e de objetos habituais a partir de uma nova iluminação, de novas conexões e de novas relações de todas essas coisas com ele mesmo. Neste processo, como temos dito, se mantém inalteradas, em princípio, suas decisões anteriores, finalidades, etc., as quais simplesmente são suspensas durante o efeito da obra (LUKÁCS, 1972, vol. 2, p. 528-29, tradução nossa).
\end{abstract}

O autor afirma que, após a vivência estética, o sujeito retorna ao plano da cotidianidade com as mesmas finalidades concretas que tinha no momento que precedia a sua experiência receptiva, pois esse tipo particular de recepção não se refere diretamente aos esforços anteriores do sujeito; mas enfatiza que essa ausência de relação entre os conteúdos prévios e posteriores do fruidor, durante a experiência estética, é meramente imediata. Tal afirmação se justifica porque a obra de arte não é, somente, um mundo fechado para si, mas age sob o receptor de modo a colocá-lo diante de um mundo que a ele faz referência, isto é, um mundo que é, em certo sentido, dele próprio. Enfatiza Lukács que a vinculação entre os conteúdos do sujeito receptor e aqueles materializados no objeto artístico será mais rica proporcionalmente à profundidade e à universalidade apresentadas nas obras.

No Depois da vivência estética, as finalidades práticas imediatas do sujeito, isto é, aquelas que se mantiveram suspensas durante o momento da fruição, não se transformam imediatamente após essa experiência. Antes de tudo, a transformação ocasionada pela vivência receptiva, seja ela consciente, inconsciente, visível ou oculta, afeta o homem inteiro, a sua relação com a vida, com o mundo, as suas atitudes diante deste e a sua interação social; aspecto que nos leva à afirmação de Tertulian de que: "O ato de contemplação estética não está, então, hermeticamente isolado do fluxo da consciência prática. Relações de osmose existem entre os dois planos" (TERTULIAN, 2008, p. 283). Somente quando esse efeito é alcançado de forma substancial é possível que, dele, se depreendam novas finalidades humanas concretas, as quais aparecem, portanto, de forma diversa daquelas que precederam a vivência artística de uma obra. Para ilustrar a afirmação 
precedente, Lukács resgata os romances do escritor russo Nikolay Gavrilovich Chernyshevsky (1828-89), os quais influenciaram o contexto da Revolução Russa:

[...] seu efeito não consiste tanto em uma simples reprodução intelectual, emocional e prática de seu conteúdo quanto no mediado efeito posterior de modos de comportamentos humanos típicos e na continuação dessa tendência até a formação de um tipo de homem, cuja ocasião antecipada, e acaso exemplar, foram certamente esses romances, os quais, devido ao seu conteúdo essencial, se enraizaram nas lutas concretas da época, lutas nas quais estão concretamente implicados os homens como homens inteiros da vida (LUKÁCS, 1972, vol. 2, p. 538, tradução nossa).

Segundo Lukács, as obras que nascem em momentos agudos de crise e de transformações sociais severas tendem a incidir mais intensamente nos comportamentos dos homens e da sociedade, modificando-os com vistas à realização de determinadas finalidades concretas exigidas pelo momento histórico em que a obra nasceu. Reproduziremos, a seguir, uma passagem longa da "Estética", contudo, absolutamente necessária, em que Lukács define o que entende como o Depois da experiência receptiva, para que possamos, por conseguinte, avançar na exposição dessa questão:

O Depois da vivência receptiva pode ser descrito simplificadamente do seguinte modo: a irrupção do meio homogêneo da individualidade da obra nas vivências do homem inteiro converte-lhe, finalmente, em receptor propriamente dito, orienta sua concentrada capacidade receptiva frente ao que Ihe é oferecido em cada caso; assim se converte em homem inteiramente disposto à recepção. O poder evocador das formas, mediado pelo meio homogêneo, mantém o encantamento desse homem frente a um mundo novo, e impõe a ele o selo de sua essência como um conteúdo novo e próprio. O Depois consiste no modo como o homem inteiro, já livre dessa influência, elabora o que fora adquirido. O adquirido é imediatamente conteúdo e, por isso, suscita no homem a tarefa de inseri-lo em sua imagem anterior do mundo e a transformá-la de modo correspondente para adaptá-la àquele [adquirido]. Porém, somente em sentido imediato, se trata de conteúdo; como este constitui o lado voltado para o receptor de uma identidade forma-conteúdo, a componente formal dessa identidade se manifesta na grande tensão e intensidade do todo, como já sabemos, além do mais a novidade da obra atua também formalmente, na medida em que todo conteúdo comunica ao receptor algo do método de sua percepção, de sua acessibilidade; por isso a percepção de novos conteúdos é, ao mesmo tempo, um estímulo e uma orientação para reconhecer também na vida o que lhe é análogo e para apropriar-se dele [dos conteúdos adquiridos]. Desta forma ocorre a passagem do homem inteiramente receptivo ao homem inteiro da cotidianidade (LUKÁCS, 1972, vol. 2, p. 536-37, tradução nossa).

As comoções e as transformações que ocorrem no sujeito receptor no Depois da experiência estética são diversas, pois variam de homem para homem. Nesse mesmo sentido, a profundidade, o alcance, o conteúdo, a duração e diversos outros fatores 
oriundos da esfera estética repercutem nos múltiplos sujeitos das formas mais distintas. Em muitas ocasiões, nos colocamos frente a uma obra de arte e seu efeito sobre nós é, praticamente, imperceptível ou, até mesmo, nulo; entretanto, outras vezes, a experiência é suficiente para provocar uma transformação completa e radical em nossas vidas, pois afeta, diretamente, aquilo que é mais essencial no que tange à vida da humanidade. Ainda que algumas obras não nos afetem substancialmente em um primeiro momento, impactando, somente, algumas manifestações periféricas da nossa vida, é possível que estas se acumulem de forma a alcançar conteúdos essenciais, o que motiva a afirmação de Lukács de que: "(...) o centro humano, esteticamente movido, não perde nunca a sua íntima vinculação com a periferia da vida" (LUKÁCS, 1972, vol. 2, p.538, tradução nossa).

Se a força das obras de arte se orienta sempre ao homem inteiro, a fim de transformá-lo em homem inteiramente; ao afetar o centro essencial daquele, que incidirá sob a periferia desse mesmo homem, duas concepções extremas sobre a esfera estética são trazidas à tona: 1) a de que a arte é uma força transformadora e, portanto, decisiva da evolução social e 2) a de que a arte não tem nenhuma influência concreta e real na vida social e prática dos homens. Esses extremos são, de acordo com Lukács, falseadores, pois o papel social da arte consiste, essencialmente, em:

[...] uma preparação anímica para as novas formas de vida, com o efeito subsidiário de que na arte se acumulam de modo vivenciável todos os valores humanos do passado, por meio dos quais a arte é capaz de mostrar de forma mais precisa as formações que se transformam totalmente no cenário histórico, com sua plena totalidade humana. Por tal motivo, é possível que a arte diga quais são os valores humanos que merecem se desenvolver, quais devem ser preservados e mantidos, e quais devem cair no esquecimento (LUKÁCS, 1972, vol. 2, p. 539-40, tradução nossa).

Levando em consideração a passagem supracitada, pode-se compreender por qual motivo Lukács não predica à arte uma força transformadora e decisiva da evolução social bem como não afirma que ela possui nula influência concreta na vida social e prática dos homens. A preocupação do autor está, essencialmente, voltada para um entendimento do fenômeno estético como "preparação anímica" para as novas formas de vida que acenam à sociedade. $\mathrm{O}$ acento, portanto, recai na ideia de preparação desse homem esteticamente enriquecido, de forma que a vivência por ele adquirida no Depois da experiência receptiva será importante para incrementar a sua capacidade de isolar os conteúdos que ainda se mantêm vivos na velha cultura, fazendo com que estes se tornem fecundos para o momento presente e, possivelmente, para um momento futuro: "A arte amplia o âmbito dos pensamentos e sentimentos dos homens porque traz à superfície da vivencialidade o 
que está objetivamente contido em uma situação histórica" (LUKÁCS, 1972, vol. 2, p.541, tradução nossa).

\section{Considerações finais}

A partir da retomada e da exposição das noções de experiência receptiva e catarsis na "Estética", concluímos que Lukács, apesar de não ter escrito um dos volumes da obra em que se concentraria efetivamente no comportamento estético, nos deu indícios robustos do que entende por experiência receptiva, argumentando fortemente acerca da importância de um entendimento da obra de arte como materialização de um mundo - de uma totalidade intensiva - cuja efetivação de sua existência é construída a partir da evocação de uma forma artística adequada pelo conteúdo que o artista se propôs a figurar. Forma e conteúdo e a relação de simbiose entre tais fatores permitem ao fruidor a vivência estética da obra de arte, consolidando a possibilidade da relação sujeito-objeto.

$\mathrm{Na}$ experiência estética receptiva, o indivíduo vivencia o mundo fechado da obra de arte, um mundo elevado e superior, de caráter verdadeiramente humano, revelado, por conseguinte, pela experiência catártica, que proporciona a humanização do sujeito estético. A catarsis, portanto, dá sustentação à missão desfetichizadora da arte ao revelar ao sujeito a fetichização subjacente à vida cotidiana. Consequentemente, a possibilidade de defesa da integridade da humanidade no plano da vida cotidiana torna-se real e objetiva, o que torna a obra de arte um veículo pedagógico, pois a relação sujeito-objeto possibilita ao receptor a percepção "natural" de alguns aspectos da vida, que, no plano disperso da cotidianidade, estão, geralmente, obscurecidos.

Esse entendimento nos conduz a uma compreensão da fruição artística como defesa da integridade da humanidade no plano da vida cotidiana e, ainda, como possibilidade de crítica da vida e da existência, pois é aberta uma via para que o sujeito estético possa transformá-las no mundo real. Diante dessa compreensão, a desfetichização e a catarsis possibilitam à arte autêntica - leia-se, para Lukács, a arte realista - a realização de um papel basilar na formação humana, pois reconcilia o sujeito com o mundo do qual ele se apartou. Ao refigurar os conteúdos essenciais da realidade no mundo fechado da obra de arte, e, ao criar um mundo elevado e superior, o fruidor passa a se reconhecer no mundo dos objetos, o que assegura a possibilidade da aproximação e, até mesmo, da identidade sujeito-objeto negada pelo trabalho estranhado.

A experiência estética permite, portanto, a não rendição do sujeito à fetichização e à alienação impregnadas no plano da realidade cotidiana, pois, ao se reconhecer no mundo dos objetos e ao se sentir parte desse mundo, o sujeito estético entende-se como seu co- 
criador, restabelecendo, por sua vez, a relação então rompida entre o homem inteiro e o homem inteiramente. Diante dessas possibilidades, a arte se apresenta como um meio para que o indivíduo possa construir, ao retornar à vida cotidiana enriquecido pela experiência estética, uma relação sujeito-objeto de base autêntica. Como já dissemos, a experiência catártica conduz o fruidor a viver o mundo como a sua pátria, pois ele se reconhece como co-criador desse mundo e como parte do gênero humano. Consequentemente se reconhece, ainda, como parte de todas as conquistas e de todos os feitos históricos da humanidade. A partir dessa experiência, ele vivencia o sentido humano, profundo e amplo de sua vida singular, sem a necessidade do aniquilamento de seus traços mais singulares. Simultaneamente, ele experimenta a sua condição como homem universal, como parte da humanidade. Esse conjunto de noções nos faz compreender a recepção artística como uma experiência em que o sujeito pode atravessar e superar a barreira da alienação, de forma a realizar a crítica e a transformação de sua existência e das relações que estabelece com o mundo. Essa retroação da vivência estética, que incide sobre a subjetividade ativa do cotidiano dos homens, é uma das mais importantes implicações da catarsis no que tange, principalmente, ao caráter social da arte.

Podemos afirmar, portanto, que, a partir da "Estética" de maturidade, Lukács delineia uma zona compartilhada entre a estética e a ética, cujo ponto de convergência se dá a partir do entendimento da catarsis como: "(...) vivência da realidade intrínseca da vida humana, cuja comparação com a realidade cotidiana produz, pelo efeito da obra, uma purificação das paixões que se transforma em ética já no Depois da obra (LUKÁCS apud PATRIOTA, 2010, p. 267). Este Depois abre a possibilidade ao sujeito fruidor de uma possível transformação existencial direcionada à realização de possibilidades humanas autênticas, mais significativas, ricas e amplas. A experiência receptiva evoca, assim, a possibilidade de um desenvolvimento humano em que o sujeito, sem apagar a sua singularidade, reivindica para si as tarefas do gênero humano, vivenciando-as como suas e compreendendo os traços comuns da vida do gênero e de sua própria existência. $O$ entendimento da eticidade apontará, segundo Lukács, para a harmonização dos interesses genéricos e particulares do indivíduo, de forma que suas tomadas de decisão terão como referência a sua própria generidade, mas orientadas, sobretudo, pela sua superação.

Nesse sentido, a obra de arte e o efeito gerado por ela no sujeito receptor nos encaminham para uma concepção de objeto artístico como a expressão de uma realidade que, embora transcenda os horizontes de vida usuais do indivíduo, aponta para a concreção de possibilidades humanas reais. É importante ressaltarmos que, mesmo as obras que versam sobre tempos remotos, ou aquelas já situadas em um tempo histórico longínquo do receptor - como o romance histórico ou as tragédias - propiciam uma vivência estética objetiva, no sentido de que propõem ao sujeito um resgate rememorativo 
de alguma experiência universal situada em um tempo histórico particular. Desta feita, afirmamos que o intuito da experiência receptiva na "Estética" não pode ser entendido como algo fechado sobre si mesmo, pois tal experiência se abre para a vida real do sujeito estético, penetrando-a, de forma que, ao fruidor, é imposto o desafio do Depois da experiência receptiva.

Por fim, acreditamos que existe uma aproximação entre arte e vida na "Estética", pois os movimentos de recepção e de criação das obras de arte assumem como princípio a vida substancial do homem e a evolução - passada, presente, ou mesmo, as possibilidades futuras - da humanidade: tal aspecto implica na percepção do sujeito da substancialidade artística como a sua própria. A justificativa para tal formulação pode ser traduzida quando, na realização do objeto estético, é revelada e efetivada a subjetividade do artista e da humanidade, movimento que aproxima, ainda mais, a relação entre arte e vida, assegurada, ainda, pela retroação da vivência estética que incide sobre a subjetividade ativa do cotidiano dos homens, ou seja, pela catarsis. 


\section{Referências}

ARISTÓTELES. Poética: tradução, prefácio, introdução, comentário e apêndices de Eudoro de Sousa. 5 ed. [S.I]: Imprensa Nacional, Casa da Moeda, 1998.

. Poética de Aristóteles. Edición trilingüe por Valentín García Yebra. Madrid: Editorial Gredos, 1974.

. Poética. 2. ed. São Paulo: ArsPoetica, 1993.

BASTOS, H. Arte e vida cotidiana: a catarsis como caminho para a desfetichização. Revista Herramienta. Disponível em: <http://www.herramienta.com.ar/coloquios-yseminarios/arte-e-vida-cotidiana-catarsis-como-caminho-para-desfetichizacao $>$. Acesso em: 12 de outubro de 2016.

CARLI, R. A estética de György Lukács e o triunfo do realismo na literatura. Rio de Janeiro: Editora da UFRJ, 2012.

COTRIM, A. A. O realismo nos escritos de Georg Lukács dos anos trinta: a centralidade da ação. 2009. 391f. Dissertação (Mestrado) - Faculdade de Filosofia, Letras e Ciências Humanas. Departamento de Filosofia, Universidade de São Paulo.

LUKÁCS, G. Arte e societá. Roma: Riuniti, 1977b.

. A Teoria do Romance. São Paulo: Editora 34, 2000.

. Conversando com Lukács - entrevista a Leo Kofler, L., Hans H. Holz, Wolfgang Abendroth. Rio de Janeiro: Paz e Terra, 1969.

. Écrits de Moscou. Paris, Editions sociales, 1974.

. Ensaios sobre literatura. Rio de Janeiro: Civilização Brasileira, 1964.

- Estetica. Barcelona: Grijalbo, v. 1, 1974.

- Estetica. Barcelona: Grijalbo, v. 2, 1972.

. Estetica. Barcelona: Grijalbo, v. 3, 1967.

. Estetica. Barcelona: Grijalbo, v.4, 1967. 
Renata Altenfelder Garcia Gallo | Catarsis e experiência receptiva na "Estética" (1963) de Georg Lukács

. Heidelberg Ästhetik. Darmsadt und Newvied: Hermann Lutcherhand Verlag, 1974a. . Il marxismo e la critica letteraria, Torino: Einaudi, 1970.

. Introdução a uma estética marxista. Trad. Leandro Konder e Carlos Nelson Coutinho. Rio de Janeiro: Civilização Brasileira, 1978.

. Problemas del Realismo. México- Buenos Aires: Fondo de Cultura Econômica, 1966.

PATRIOTA, R. A relação sujeito-objeto na Estética de Georg Lukács: reformulação e desfecho de um projeto interrompido. 2010.284 f. Tese (Doutorado) - Faculdade de Filosofia e Ciências Humanas, Departamento de Filosofia, Universidade Federal de Minas Gerais.

TERTULIAN, N. Lukács: Etapas De Seu Pensamento Estético. São Paulo: UNESP, 2008. 